\title{
岩塊モデルによる地下空洞の地下水解析
}

\section{GROUNDWATER ANALYSES OF ROCK CAVERN BY MEANS OF ROCK BLOCK MODEL}

\author{
佐 藤邦 明* • 伊 藤 洋** \\ By Kuniaki SATO and Yo ITO
}

\begin{abstract}
Numerous rock caverns are in use for the purpose of underground electric power stations, the fuel stock piling and the repository of radioactive nuclides. This paper studies the groundwater motion in fractured rock masses by taking the deformation of fractures and rock into consideration, and the groundwater movement around cavern is analyzed by applying the rock block model. The theoretical results are compared with those of field measurements.
\end{abstract}

\section{1.はじめに}

岩盤地下空洞は地下発電所，燃料地下備蓄，放射性廃 棄物の地下格納, 地下空間への温水や圧縮空気貯蔵, 生 産工場立地などその利用形態は多様であり，近年非常に 注目されている1) -4).これらにかかわる技術的課題はい ろいろであろうが大別すると，(1)岩盤空洞自体の力学的 安定性，(2)地下水諸問題，(3)伝熱・拡散，(4)安全性と実 用性，(5)環境問題などに分けられよう．中でも(2)，(3)は 地下水理・水文現象亡深くかかわってくる．従来，岩盤 地下空洞の水理解析はしばしば均質場の二次元流および 三次元流として扱われたが5) 7)，亀裂系を含む岩盤と間 隙水は共存して挙動するものであって，両者を一体化し て取り扱わねばならないことがある。たとえば，地震時 の水圧と岩盤の連成挙動，透水係数の空間分布や空洞掘 削時における周辺地山のゆるみ領域の形成と湧水量の関 係，さらに空洞掘削による地山・地表の沈下の問題など 地山と水の挙動を表裏一体として取り扱う必要があろ う.この種の問題の足掛りとして, Snow $(1968)^{8)}$, 佐

* 正会員 工博 埼玉大学助教授 工学部地盤水理実験施設 （テ338 浦和市下大久保 255）

** 正会員 (株) 熊谷組原子力開発室土木技術部 (埼玉大学研 究生）（テ 162 新宿区津久戸町 17-1）
藤 $(1982)^{9)}$ の岩塊ブロックモデルが知られているが, これを実際に空洞の水理解析に応用した例は少なく，佐 藤ら $(1982)^{9)}$ によるものが最初であろう。この場合に， 地下水の挙動に伴って, 割れ目系とそこにある割れ目内 壁の粗度や介在物に加えて岩石自体の変形が加わること になるため, 計算はかなり複雑なものとなる，佐藤らは 地山の水平変位を許さず, 鉛直変形のみを加味した解析 を行っている. しかし, この取扱いでは, 特に空洞周辺 近傍の地山と地下水の運動をうまく説明できないところ があって，必ずしも十分なものとはいえない，そこで， 空洞周辺の岩盤挙動を水の運動と合体として解明するた めには適切な地山モデルの導入に加え, 解析手法ととも に制約条件をより実際に近いものにすること，さらに潜 在的初期地圧の影響を加味して解析する必要があろう.

本論はこのような観点に立って, 間隙に介在物のある 亀裂系岩盤を岩塊と弾性介在物の集合体としてモデル化 し, 地山応力と地下水運動とを連成させて解析する理論 を展開して, 地下空洞の水理解析をいくつか試み, 理論 と現地計測の両面より量的検討を加えたものである.さ らに, 本論では実際の岩盤地山でルジオン試験によって 測定された透水係数の深度分布，および地下空洞掘削後 の現場におけるゆるみに関する実測結果との対比も行 う. 従来, 理論的, かつ現象的にうまく説明されていな 
かった岩盤地山の透水特性にいくつかの新しい知見を得 ることができたのでここに報告する.

\section{2. 岩盤モデルとその理論的透水係数}

岩盤地山は, Fig. 1 に示したように一般に岩質自体 (岩 石）とその割れ目系により構成されており, 元来二重空 隙系の性質をもっている．前者は，それ自体の透水性は 小さくとも多孔質であり潜在的なミクロ空隙をもち，後 者は地山形成後の地山応力場の変化や風化に起因して生 まれ，それが二次空隙系として岩盤浸透流を支配するこ とが多いと考えられている．同時に，図において各岩塊 の凹凸は互いに凸な部分で接触し，場合によって風化物 を含み,この接触点は応力の変化に伴って変化しゃすく, 割れ目幅も動的に変化するものと考えられる ${ }^{10)}$.こう いったことをふまえ，Fig. 2 に示した岩塊モデルは，特 にこのような岩盤地山の岩盤割れ目系の透水性に力点を 置いて岩質部は不透水性弾性立方体ブロック集合によっ て,また, 割れ目部の岩塊接触部分は弾性介在柱でモデ

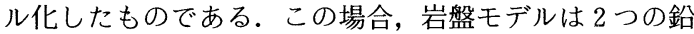
直方向割れ目 $f_{2}, f_{3}$ と水平割れ目 $f_{1}$ をもつ. 次に, こ のような岩塊モデルを用いて，岩盤地山の透水性がどの ように表わされるか, 具体的にその定式化を行ってみる.

まず，岩塊ブロックの単一割れ目 $f_{i}$ の透水係数 $k_{f i}$ は,平行間隙を流れる粘性流として次のように表わせる.

$$
k_{f_{i}}=\frac{1}{3} \frac{g}{\nu} d_{i}^{2}
$$

ここに, $g$ : 重力加速度, $\nu$ : 水の動粘性係数, $d:$ : 割 れ目幅の $1 / 2, i:$ 割れ目の方向成分 $(i=1,2,3)$, で ある.いまの場合, その割れ目系の流れの透水係数 $k_{i}$ は,

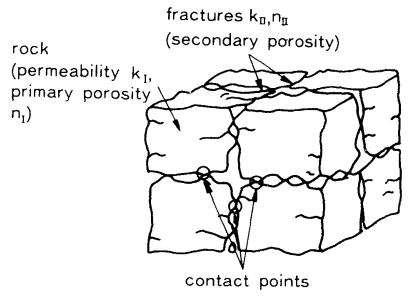

Fig. 1 Fractured rock mass.

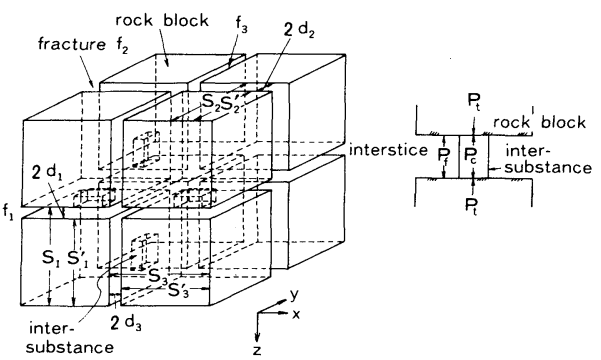

Fig. 2 Rock mass model by rock blocks.
岩自身の透水性はないとしているから，割れ目の分布間 隔 $s_{i}$ を導入すると次式で与えられる.

$$
k_{i}=k_{s_{i}} \frac{2 d_{i}}{s_{i}}=\frac{2}{3} \frac{g}{\nu} \frac{d_{i}^{3}}{s_{i}}
$$

次に, Fig. 2 に示した任意割れ目の分布間隔 $s_{i}$ ，およ び割れ目幅 $2 d_{i}$ は次のような関係式によって表わせる。

$$
\begin{aligned}
& s_{i}=s_{i}^{\prime}+2 d_{i}, \Delta s_{i}=\Delta s_{i}^{\prime}+\Delta 2 d_{i}, \\
& 2 d_{i}=2 d_{0 i}+\Delta 2 d_{i}, \quad s_{i}=s_{0 i}+\Delta s_{i}
\end{aligned}
$$

ここに, $s_{i}^{\prime}$ : ブロックの辺長, $\Delta$ : 諸量の基準値からの 変化量, $i$ : 割れ目の方向成分 $(i=1,2,3)$, であり, 添字 0 は付加応力変化のないとき (基準状態) の諸值を 意味する。

一方，同図中の下側に示したように全応力 $P_{t}$, 有効 応力 $P_{c}$, 間隙水圧 $P_{f}$ の関係は，ある任意の割れ目に 注目すると,

$$
P_{t i}=P_{f}+P_{c i}, \Delta P_{t i}=\Delta P_{f}+\Delta P_{c i}(i=1,2,3) \cdots(5)
$$

となる.さらに，このモデルにおける割れ目中に存在す る介在物を弾性体の角柱であるとすれば，割れ目幅の基 準状態からの変位量 $\Delta 2 d_{i}$ は, 次のように表わせる ${ }^{11}$.

$$
\Delta 2 d_{i}=-\frac{2 d_{0 i}}{a_{i} E_{c}} \Delta P_{c i}+\frac{2 d_{0 i} M_{c}}{E_{c}} \Delta P_{f}
$$

ここに, $E_{c}$ : 介在柱の弾性係数， $a_{i}$ : 介在柱の断面積 が割れ目の面積に占める割合, $M_{c}$ : 介在柱のポアソン 比，である。

また， $a_{i}$ の変化は変形の過程で微少であって,$a_{i} \ll 1$ であるとして介在柱自体は割れ目中の流れに影響を及ぼ さないものと考え得る. 式（6）に式（5) を代入して, $P_{c i}$ を消去し， $a_{i} M_{c} \ll 1$ を考慮すると $\Delta 2 d_{i}$ は次のよう に書ける.

$$
\Delta 2 d_{i} \doteqdot \frac{2 d_{0 i}}{a_{i} E_{c}}\left(\Delta P_{f}-\Delta P_{t i}\right) \quad(i=1,2,3)
$$

同様に, ブロックの辺長 $s_{i}^{\prime}$ の変位量 $\Delta s_{i}^{\prime}$ は, Fig. 2 の ような状態を考えて,

$$
\begin{gathered}
\Delta s_{i}^{\prime}=-\frac{s_{0 i}^{\prime}}{E_{r}} \Delta P_{t i}+\frac{M_{r} s_{0 i}^{\prime}}{E_{r}} \Delta P_{t j}+\frac{M_{r} s_{0 i}^{\prime}}{E_{r}} \Delta P_{t h} \cdots \cdots(8) \\
(i, j, k=1,2,3, \quad i \neq j \neq k)
\end{gathered}
$$

となる.ここに, $E_{r}$ : 岩ブロックの弾性係数, $M_{r}$ : 岩 ブロックのポアソン比, である.

したがって，まず式（7)，（8）を式（3）に代入し て $\Delta s_{i}$ を決めて式 $(4)$ から割れ目の分布間隔 $s_{i}$ を求 め, 次に式 (4), (7) 加割れ目幅 $2 d_{i}$ を求めること ができる．よって，結果的にそれらを用いて式 (2) か ら全応力および間隙水圧の変化を考慮した岩盤の透水係 数が次のように求まる.

$$
k_{0 i} \frac{\left\{1+\frac{1}{a_{i} e_{c}}\left(\frac{\Delta P_{f}}{E_{r}}-\frac{\Delta P_{t i}}{E_{r}}\right)\right\}^{3}}{1+\frac{s_{0 i}^{\prime}}{S_{0 i}}\left\{\lambda_{i} \frac{\Delta P_{f}}{E_{r}}-\left(1+\lambda_{i}\right) \frac{\Delta P_{t i}}{E_{r}}+M_{r} \frac{\Delta P_{t j}}{E_{r}}+M_{r} \frac{\Delta P_{t k}}{E_{r}}\right\}}
$$




$$
\begin{aligned}
k_{0 i}= & \frac{2}{3} \frac{g}{\nu} \frac{d_{0 i}^{3}}{s_{0 i}}, \lambda_{i}=\frac{1}{a_{i} e_{c}} \frac{2 d_{0 i}}{s_{0 i}^{\prime}}, e_{c}=\frac{E_{c}}{E_{r}} \\
& (i, j, k=1,2,3, \quad i \neq j \neq k) \cdots \cdots \cdots
\end{aligned}
$$

したがって, $x, y, z$ 座標軸方向の透水係数 $k_{x}, k_{y}$, $k_{z}$ は Fig. 2 および Fig. 4 (後述)で示した鉛直割れ目 $f_{2}, f_{3}$ と水平割れ目 $f_{1}$ からそれぞれの主軸方向成分に 分けて次式で表わすことができる.

$$
k_{x}=k_{1}+k_{2}, k_{y}=k_{1}+k_{3}, k_{z}=k_{2}+k_{3}
$$

よって, 式（9），(10）が任意の全応力・間隙水圧下 における岩盤地山透水係数算定式ということになるが, 式（9）をより実際に即したものとするため, 鉛直方向 の全応力に対する水平応力の比，つまり側圧係数 $K$ を 導入する，もし，定式化の便宜上地表面と地下水面が一 致しているものとすると, 全応力 $P_{t}$ および間隙水圧 $P_{f}$ は静水圧的に考えて次のように表わすことができる.

$$
\left.\begin{array}{l}
P_{t i}=K P_{t 1}, \Delta P_{t i}=K \Delta P_{t 1}(i=2,3) \\
P_{t 1}=\gamma_{r} z, \quad P_{f}=\gamma_{\omega} z
\end{array}\right\}
$$

ここに, $\gamma_{r}$ : 岩ブロックの単位体積重量, $z$ : 地表から の深さ, $\gamma_{\omega}$ : 水の単位体積重量, である.

このような考え方に立って，あるつり合い状態にある 初期地山における透水係数は式（9)，(10)，(11）を用 いて表わすことが可能となる.

\section{3. 流れの基礎式}

ここでは, 上述した透水係数の理論的関係を応用して, 岩塊モデルにおける地下水流れの基礎式を誘導してみる こととする.

常套手段として, 微小直六面体コントロールボリュー ム $\Delta V=\Delta x \Delta y \Delta z$ における流体質量の収支を考えると, 周知のように流れの連続方程式は次のように書ける.

$$
\begin{aligned}
& -\left\{\frac{\partial}{\partial x}\left(\rho q_{x}\right)+\frac{\partial}{\partial y}\left(\rho q_{y}\right)+\frac{\partial}{\partial z}\left(\rho q_{z}\right)\right\} \Delta x \Delta y \Delta z \\
& =\frac{\partial}{\partial t}(\rho n \Delta x \Delta y \Delta z)
\end{aligned}
$$

ここに, $\rho$ : 水の密度, $q_{x}, q_{y}, q_{z}: x, y, z$ 方向流速,

$$
n: \text { 空隙率, } t: \text { 時間, である. }
$$

式 (12) の右辺各項に 1つずつ注目すると, まず, 密度 の時間変化率は,

$$
\frac{\partial \rho}{\partial t}=\rho \frac{\gamma_{\omega}}{E_{\omega}} \frac{\partial h_{f}}{\partial t}
$$

となる.ここに, $E_{\omega}$ : 水の体積弾性係数, $h_{f}$ : 間隙水 圧 $P_{f}$ の水頭値 $\left(h_{f}=P_{f} / \rho g\right)$ とする.

次に, 空隙率 $n$ はFig. 2 に示した関係より次のよう な関係をもつ。

$$
n=\sum_{i=1}^{3} n_{i}, \quad n_{i}=\frac{2 d_{i}}{s_{i}} \quad(i=1,2,3)
$$

したがって，式（3)，（4)，（7)，（8）より $n_{i}$ は次 のように書くことができる.

$$
n_{i}=\frac{2 d_{0 i}}{s_{0 i}}
$$

$$
\times\left[\frac{1+\frac{1}{a_{i} e_{c}}\left(\frac{\Delta P_{f}}{E_{r}}-\frac{\Delta P_{t i}}{E_{r}}\right)}{1+\frac{s_{0 i}^{\prime}}{S_{0 i}}\left\{\lambda_{i} \frac{\Delta P_{f}}{E_{r}}-\left(1+\lambda_{i}\right) \frac{\Delta P_{t i}}{E_{r}}+M_{r} \frac{\Delta P_{t j}}{E_{r}}+M_{r} \frac{\Delta P_{t k}}{E_{r}}\right\}}\right]
$$$$
(i, j, k=1,2,3, \quad i \neq j \neq k)
$$

また，一般に $n_{i}$ の時間変化は,

$$
\frac{\partial n_{i}}{\partial t}=\frac{\partial n_{i}}{\partial P_{f}} \frac{\partial P_{f}}{\partial t}+\frac{\partial n_{i}}{\partial P_{t i}} \frac{\partial P_{t i}}{\partial t}+\frac{\partial n_{i}}{\partial P_{t j}} \frac{\partial P_{t j}}{\partial t}+\frac{\partial n_{i}}{\partial P_{t k}} \frac{\partial P_{t k}}{\partial t}
$$

となるから，式（16）に式（15）を代入して整理すると,

$$
\begin{aligned}
\frac{\partial n}{\partial t} & =\sum_{i=1}^{3} \lambda_{i}\left(\frac{s_{0 i}^{\prime}}{s_{0 i}}\right)^{2} \zeta_{i a} \frac{\gamma_{\omega}}{E_{r}} \frac{\partial h_{f}}{\partial t}-\sum_{i=1}^{3} \lambda_{i}\left(\frac{s_{0 i}^{\prime}}{s_{0 i}}\right)^{2} \zeta_{i b} \frac{\gamma_{\omega}}{E_{r}} \frac{\partial h_{t i}}{\partial t} \\
& -\sum_{i=1}^{3} \lambda_{i}\left(\frac{s_{0 i}^{\prime}}{s_{0 i}}\right)^{2} \zeta_{i c} \frac{\gamma_{\omega}}{E_{r}} \frac{\partial h_{t j}}{\partial t}-\sum_{i=1}^{3} \lambda_{i}\left(\frac{s_{0 i}^{\prime}}{s_{0 i}}\right)^{2} \zeta_{i c} \frac{\gamma_{\omega}}{E_{r}} \frac{\partial h_{t k}}{\partial t}
\end{aligned}
$$

と表わせる.ここに，

$$
\begin{gathered}
\zeta_{i a}=\left(\frac{s_{0 i}^{\prime}}{s_{0 i}}-a_{i} e_{c} \lambda_{i}-\frac{\gamma_{\omega}}{E_{r}} \Delta h_{t i}+\frac{M_{r} \gamma_{\omega}}{E_{r}} \Delta h_{t j}+\frac{M_{r} \gamma_{\omega}}{E_{r}} \Delta h_{t k}\right) \\
/ \eta, \quad \zeta_{i b}=\left\{\frac{s_{0 i}^{\prime}}{s_{0 i}}-a_{i} e_{c}\left(1+\lambda_{i}\right)-\frac{\gamma_{\omega}}{E_{r}} \Delta h_{f}+\frac{M_{r} \gamma_{\omega}}{E_{r}} \Delta h_{t j}\right. \\
\left.+\frac{M_{r} \gamma_{\omega}}{E_{r}} \Delta h_{t k}\right\} / \eta, \quad \zeta_{i c}=M_{r}\left(a_{i} e_{c}+\frac{\gamma_{\omega}}{E_{r}} \Delta h_{f}\right. \\
\left.-\frac{\gamma_{\omega}}{E_{r}} \Delta h_{t i}\right) / \eta, \\
\eta= \\
\quad\left[1+\frac{s_{0 i}^{\prime}}{s_{0 i}}\left\{\lambda_{i} \gamma_{\frac{\omega}{E_{r}}} \Delta h_{f}-\left(1+\lambda_{i}\right) \frac{\gamma_{\omega}}{E_{r}} \Delta h_{t i}+\frac{M_{r} \gamma_{\omega}}{E_{r}} \Delta h_{t j}\right.\right. \\
\left.\left.+\frac{M_{r} \gamma_{\omega}}{E_{r}} \Delta h_{t k}\right\}\right]^{2}, \quad(i, j, k=1,2,3, i \neq j \neq k) \\
\text { ここに, } h_{t} \text { : 全応力 } P_{t} \text { の水頭換算值, である. }
\end{gathered}
$$

さらに, 直六面体コントロールボリュームの $x, y, z$ 方向の辺長時間変化は,

$$
\begin{aligned}
& \frac{\partial(\Delta x)}{\partial t}=\frac{\Delta x}{s_{2}} \frac{\partial s_{2}}{\partial t}=\frac{\Delta x}{s_{02}+\Delta s_{2}} \frac{\partial\left(\Delta s_{2}\right)}{\partial t} \\
& =\frac{\Delta x / s_{02}}{1+\Delta s_{2} / s_{02}} \frac{\partial\left(\Delta s_{2}\right)}{\partial t}, \Delta s_{2} / s_{02} \ll 1 \\
& \doteqdot \frac{\Delta x}{s_{02}} \frac{\partial\left(\Delta s_{2}\right)}{\partial t} \\
& \frac{\partial(\Delta y)}{\partial t}=\frac{\Delta y}{s_{03}} \frac{\partial\left(\Delta S_{3}\right)}{\partial t} \cdots(19), \frac{\partial(\Delta z)}{\partial t}=\frac{\Delta z}{s_{01}} \frac{\partial\left(\Delta s_{1}\right)}{\partial t}
\end{aligned}
$$

と書ける.ここに, $d(\Delta x) / \Delta x=d\left(s_{2}\right) / s_{2}$, $d(\Delta y) / \Delta y=d\left(s_{3}\right) / s_{3}, d(\Delta z) / \Delta z=d\left(s_{1}\right) / s_{1}$, とする. これより, 式 (18)〜 (20) は式 (3), ( 7 ), ( 8 ) を用い て次のように表わせる.

$$
\begin{aligned}
& n \frac{\partial(\Delta x)}{\partial t} \Delta y \Delta z+n \frac{\partial(\Delta y)}{\partial t} \Delta x \Delta z+n \frac{\partial(\Delta z)}{\partial t} \Delta x \Delta y \\
& =n \sum_{i=1}^{3} \frac{s_{0 i}^{\prime}}{s_{0 i}}\left\{\lambda_{i} \frac{\gamma_{\omega}}{E_{r}} \frac{\partial h_{f}}{\partial t}-\left(1+\lambda_{i}\right) \frac{\gamma_{\omega}}{E_{r}} \frac{\partial h_{t i}}{\partial t}\right.
\end{aligned}
$$




$$
\left.+\frac{M_{r} \gamma_{\omega}}{E_{r}} \frac{\partial h_{t j}}{\partial t}+\frac{M_{r} \gamma_{\omega}}{E_{r}} \frac{\partial h_{t k}}{\partial t}\right\}
$$

さらに, $h=h_{f}+z(h:$ ピエゾ水頭 $)$ を導入し, $\partial h_{f} /$ $\partial t=\partial h / \partial t$ と書き, またダルシーの法則より,

$$
q_{x}=-k_{x} \frac{\partial h}{\partial x}, q_{y}=-k_{y} \frac{\partial h}{\partial y}, q_{z}=-k_{z} \frac{\partial h}{\partial z}
$$

と書けるので, 式 (12) は式 (13)，(17)，(21),

を代入して，整理すれば最終的に，

$$
\begin{aligned}
& \frac{\partial}{\partial x}\left(k_{x} \frac{\partial h}{\partial x}\right)+\frac{\partial}{\partial y}\left(k_{y} \frac{\partial h}{\partial y}\right)+\frac{\partial}{\partial z}\left(k_{z} \frac{\partial h}{\partial z}\right) \\
& =S_{f} \frac{\partial h}{\partial t}-S_{t a} \frac{\partial h_{t i}}{\partial t}-S_{t b} \frac{\partial h_{t j}}{\partial t}-S_{t c} \frac{\partial h_{t k}}{\partial t} .
\end{aligned}
$$

と書けることになる.ここに，

$$
\begin{aligned}
& S_{f}=\left\{\frac{n}{e_{\omega}}+\sum_{i=1}^{3} \lambda_{i}\left(\frac{s_{0 i}^{\prime}}{s_{0 i}}\right)\left(1+n \zeta_{i a} \frac{s_{0 i}^{\prime}}{s_{0 i}}\right)\right\} \frac{\gamma_{\omega}}{E_{r}} \\
& S_{t a}=\left\{\sum_{i=1}^{3}\left(\frac{s_{0 i}^{\prime}}{S_{0 i}}\right)\left(\lambda_{i} \frac{s_{0 i}^{\prime}}{s_{0 i}} \zeta_{i b}+n+n \lambda_{i}\right)\right\} \frac{\gamma_{\omega}}{E_{r}} \\
& S_{t b}=S_{t c}=\left\{\sum_{i=1}^{3}\left(\frac{s_{0 i}^{\prime}}{s_{0 i}}\right)\left(\lambda_{i} \frac{s_{0 i}^{\prime}}{s_{0 i}} \zeta_{i c}-n M_{r}\right)\right\} \frac{\gamma_{\omega}}{E_{r}} \\
& e_{\omega}=E_{w} / E_{r}, \quad(i, j, k=1,2,3, \quad i \neq j \neq k)
\end{aligned}
$$

である。

結局, 式 (23) が岩塊モデルによる岩盤地山の地下水 流れの支配方程式となるが，右辺の非定常項は間隙水圧 $P_{f}$, および全応力成分 $P_{t i}, P_{t j}, P_{t k}$ による影響を受け ることになる.

\section{4. 透水係数の理論的性質と実測との比較}

岩塊モデルから導かれた透水係数式（9）によって実 際の透水係数の深度分布がどの程度説明できるか, ルジ オン試験によって得られた現地実測データを用いて吟味 してみることとする.

まず，初めに透水係数式（9）の理論的性質を調べる ことにする．式（9）に着目すると，分母は深度がかな
り大きくならない限り（深さ $500 \mathrm{~m}$ 程度以内），実際に 考え得る定数の程度|(Table 1 参照) では, $\lambda \Delta P_{f} /$ $E_{r}<2.0 \times 10^{-3},\left\{\left(1+\lambda+M_{r}\right) K+M_{r}\right\} \Delta P_{t 1} / E_{r}<1.0 \times 10^{-2}$, $s_{0 i}^{\prime} / s_{0 i} \approx 1$ ，となり，分母を 1 としても誤差は高々 $1 \%$ 以内にとどまる．つまり，実用上は岩盤地山の透水性は 同式の分子によって支配されていることになる.そこで， Fig. 2 のモデルにおける各割れ目方向成分 $f_{1}, f_{2}, f_{3}$ の 透水係数 $k_{1}, k_{2}, k_{3}$ が深度変化によって基準状態 $(z$ $=0$ における值）からどう変わるかを示したものが Fig. 3 である.この図では，等方性地山と考えて $\gamma_{\omega}=$ $9.8 \mathrm{kN} / \mathrm{m}^{3}, \quad \gamma_{r}=25.5 \mathrm{kN} / \mathrm{m}^{3}, a E_{c}=1.96 \mathrm{MN} / \mathrm{m}^{2}($ 後述 Fig. 6 を参照) を一定と与え，初期地圧にかかわる側圧 係数をパラメーターに $K=0.3 \sim 1.5$ 亡変えて計算した ものである.これより，水平方向の割れ目成分 $f_{1}$ の透 水係数 $k_{1}$ は，深度に依存して著しく低下していること がわかる．他方，鉛直方向割れ目 $f_{2}, f_{3}$ のそれら $k_{2}$, $k_{3}$ は，むしろ側圧係数 $K$ によって大きく変わり， $K>$ 0.4 ではそれらは低下傾向をとるが， $K=0.3$ になると 逆に増加している，つまり，側圧係数が小さいと側圧方 向の応力変化量が少なくなるためその割れ目幅の変化が 小さいことになる．結局， $K>1$ の場合は $k_{2}$ は $k_{1}$ より 深さによって急に低下するが， $K<1$ では $k_{1}$ より低下 の程度は少なくなることが認められる.

次に，Fig. 3 による $k_{1} ， k_{2}, k_{3}$ を用いて $x, y, z$ 方 向の透水係数比 $k_{x} / k_{0 x}, k_{y} / k_{0 y}, k_{z} / k_{0 z}$ と深度 $z$ の関 係を示したのがFig. 4 である. 図中，実線は水平方向透 水係数 $k_{x}$, 破線は鉛直方向透水係数 $k_{z}$ の深度変化を示 している.透水係数は, 全体に側圧係数 $K$ が大きいほよ゙, その減少が著しくなり，Kが大きいとそれだけ側方の 全応力増分 $\Delta P_{t i}$ 亡間隙水圧の増分 $\Delta P_{f}$ の差が大きく なって，しかもそれが深さ方向に 3 乗できいてくること

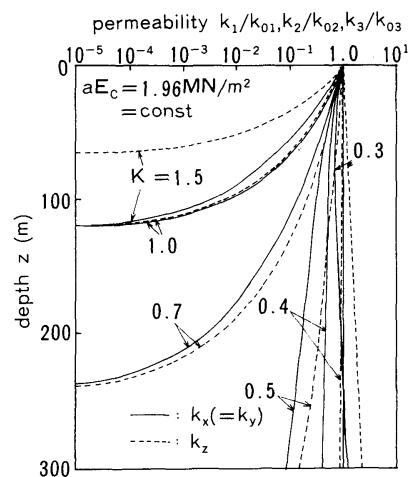

Fig. 3 Theoretical permeability distributions $k_{1} / k_{01}, k_{2} /$ $k_{02}, \quad k_{3} / k_{03}$ with depth $z$ for different parameter $K$.

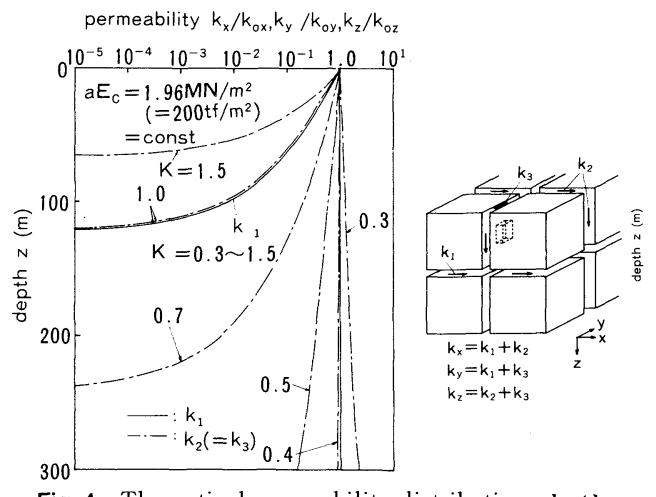

Fig. 4 Theoretical permeability distributions $k_{x} / k_{0 x}$, $k_{y} / k_{0 y}, k_{z} / k_{0 z}$ with depth $z$ for different parameter $K$.

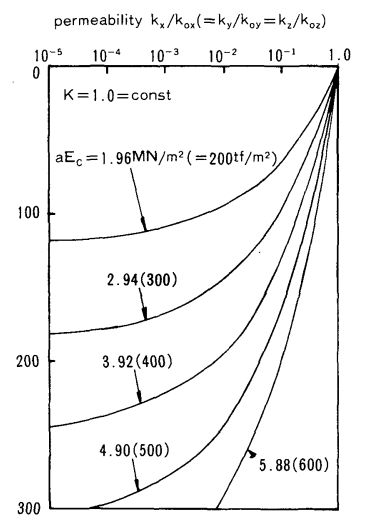

Fig. 5 Theoretical permeability distributions $k_{x} / k_{0 x}$ with depth $z$ for different parameter $a E_{c}$. 
になる. $K>1$ の場合は $k_{z}$ の方が $k_{x}$ よりその低下の傾 向が急であるが，また， $0.4 \leq K \leq 1$ の場合は逆に $k_{x}$ の 方が低下の程度がやや大きくなる，しかしながら， $K=$ $0.7,1.0$ の場合の $k_{x}, k_{z}$ の低下率は, 深さが増すにつ れて顕著に増大するのに対し， $K=0.4,0.5$ の場合に それらは小さくなっている. また, $K=0.3$ の場合, $k_{x}$ は深さ $z$ が小さいときはやや減少するもののある程度 深くなってくると, 逆に増加するといった結果となって いる.これは，K=0.3のときには式（11）において $K \gamma_{r} z<\gamma_{\omega} z$ となって, $\Delta P_{c 2(c 3)}=\Delta P_{t 2(t 3)}-\Delta P_{f}<0$ とな る. つまり水平方向の有効応力が負の值をもち介在柱が 引張応力を受けることになるが, この傾向は自然初期地 山では考えにくい. さらに, Fig. 5 は, パラメーター $a E_{c}$ の影響を検討するため, $K=1.0$ を一定とし後述す る実测データ (Fig.6参照) を参考にして $a E_{c}$ の值を 変えて深度 $z$ と水平方向透水係数 $k_{x} / k_{0 x}$ の関係を示し たものである.これによれば， $a E_{c}$ の值が大きいほよ゙， つまり, 介在柱の占める面積, あるいはその弾性係数が 大きいほど透水係数 $k$ の変化はゆるやかであり, 側圧 係数 $K$ とともに $a E_{c}$ が割れ目の変化特性, すなわち亀 裂系岩盤地山の透水性を支配する重要なパラメーターと なっていることがわかる.

次に, 上述の計算と同様にして, 式 $(9)$ から求まる深度 $z$ に伴う水平方向透水係数 $k_{x}$ の変化と, いろいろな研 究者によってまとめられたルジオン試験による実測鉛直 方向透水係数分布を比較したものが Fig. 6 である ${ }^{12) ~ 14) . ~}$ 図は，側圧係数 $K=0.7 ， 1.0 ， 1.5$ の場合に基準状態の 透水係数 $k_{0 x}$ をおのおの (a) Loc. I では, $k_{0 x}=5.0 \times$ $10^{-6} \mathrm{~m} / \mathrm{s}$, Loc. II では, $K_{0 x}=6.0 \times 10^{-7} \mathrm{~m} / \mathrm{s}$, (b)の No. 1 , $8.0 \times 10^{-10} \mathrm{~m} / \mathrm{s}$, No. 2, $1.0 \times 10^{-9} \mathrm{~m} / \mathrm{s}$, (c) の Loc. A, $6.2 \times 10^{-8}$, Loc. B $3.0 \times 10^{-6} \mathrm{~m} / \mathrm{s}$ ，と仮定し， $a E_{c}$ を 適切に選んで透水係数の深度変化曲線が実線で示してあ る. いずれも実測值と理論値は定量的によく一致してお り，パラメーター $K$ および $a E_{c}$ が実際に即したもので あれば，本モデルで十分実際の初期地山透水係数の変化 が説明でき，かつ亀裂系岩盤の透水特性を表現し得るこ とがわかる. また，透水係数の低下率は深度が大きくな るにつれてやや大きくなるが，基準状態の透水係数 $k_{0}$ が小さいとそれは小さくなることが判読できる.

そこで, Fig. 6 の対比之上述したFig. 4, 5 の性質を 考え合わせると, 側圧係数 $K$ が 0.5 以下の值をもつと, 透水係数の低下率は，深度が増すに伴って不自然に小さ くなり, 実測透水特性と矛盾するので $K$ は $0.7 \sim 1.5$ 程 度の值をもつことが伺える。このことは実際の地山では 初期岩盤地山の自重による応力のほかに地質応力（地壳 変動, 火山活動など）を受け，単純な静水圧的一次地圧 とは異なっているものと判断される。これに関しては従
来初期地山における地圧と掘削応力解放後のそれと区別 しており, 現地の側圧係数值として $K=0.7 \sim 1.4$ 程度 の值をとっていることから Fig. 6 の検討の妥当性が十分 理解できるところである，つまり，岩盤地山の透水特性 といった観点からしても初期地圧の存在が確認されたわ けで，このことは逆に本モデルの有用性を裏付けている ものといえよう. 現時点では側圧係数 $K$ の納得できる

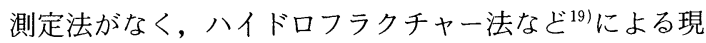
地試験が試みられている。この方法による結果から $K$ $=0.7 \sim 1.5$ は大過ない值であろう. 次に, こういった 実測データに根拠をもつ基準状態の透水係数 $k_{0}$ と介在 柱にかかわる定数 $a E_{c}$ の関係を示したのが Fig. 7 であ る.これより, $a E_{c}$ は $k_{0}$ が小さくなるにつれて大きく

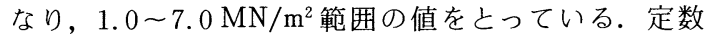
$a E_{c}$ は現地で直接測定し難いと思えるが, 同図は現地 の透水係数分布から得られる基準状態の透水係数 $k_{0}$ 亡 側圧係数 $K$ を知ることからそれをある程度推定し得る ことを示唆している.

以上，本論のモデルから得られた透水係数の性質を実
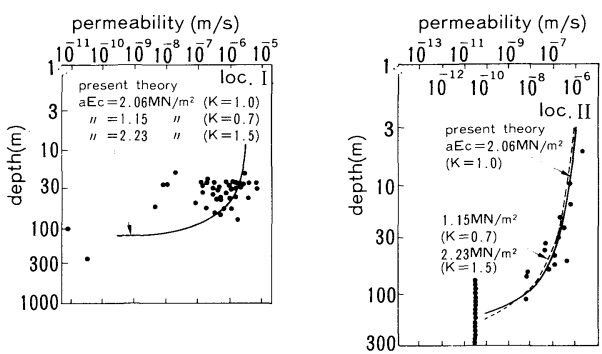

(a) permeability change with depth by Carlson et al. ${ }^{13)}$
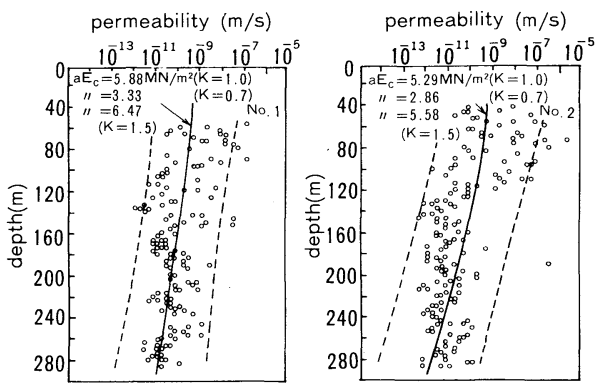

(b) permeability change with depth by Gale et al. ${ }^{14}$ )

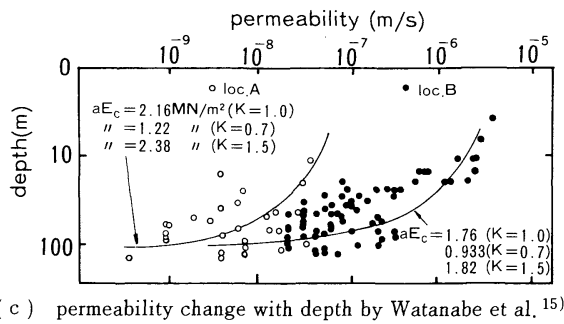

Fig. 6 Comparison between theoretical and measured permeabilities with depth at different locations. 


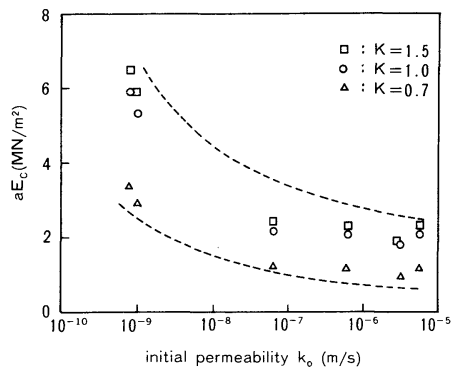

Fig. 7 Relationships between parameter $a E_{c}$ and initial permeability $k_{0}$.

測データとの比較も含めいろいろな角度から検討を加え た. 亀裂系岩盤地山の透水係数深度分布は基準状態の透 水係数 $k_{0}$, および初期地圧を知って介在柱にかかわる 定数 $a E_{c}$ を決めれば, ある程度推定し得ることがわかっ た。 また, 従来岩盤力学の分野でいわれてきた初期地圧 の概念が岩盤地山の透水性の解明にも不可欠であること が確認されたものといえ，興味深いところである.

\section{5. 岩盤空洞の地下水解析への適用}

理論と現場実測結果の両面より岩盤地山の透水性を把 握することができたが，ここではその結果を踏まえて地 下空洞の地下水流に得られた理論を適用し，地山の応力 や間隙水圧の変化に伴う透水係数の空間分布の変化, 特 に空洞周辺のゆるみ領域におけるそれが岩盤浸透流に及 ぼす影響について検討することとする.一般に,トンネル や空洞を一次応力場にある岩盤地山で掘削したとき，掘 削空洞周囲において岩盤応力の開放が起こってゆるみ帯 が発生し,その中では岩盤は塑性を呈すといわれ，そこで の透水問題については長い間未解明のままであった。

\section{（1）解析モデルと条件}

解析モデルは，実際規模の単設空洞を想定して Fig. 8 のように設定する．このモデルは，不透水性基盤上に亀 裂系をもつ無数の岩塊集合からなる透水性岩盤地山があ り, 岩盤地山の上部に沖積層が帯水しており，その岩盤 地山内に上半円形の空洞が掘削されたとするものであ る。また，地下空洞は奥行方向 $(y$ 方向) には十分長く 弾性論における平面ひずみ状態にあるとする.

Table 1 には解析条件を示している. 空洞寸法および 地山規模は, 空洞幅 $B=20 \mathrm{~m}$, 空洞高さ $H_{c}=30 \mathrm{~m}$, 上 半径 $r=10 \mathrm{~m}$, 沖積層厚さ $H_{w}=20 \mathrm{~m}$, 地山厚さ $H_{r}=$ $140 \mathrm{~m}, H_{s}=10 \mathrm{~m}$, 全地下水深 $H_{0}=150 \mathrm{~m}$, 土被り $H_{a}=$ $50 \mathrm{~m}$, 空洞から不透水基盤までの梁さ $H_{u}=60 \mathrm{~m}$, 水平 境界長さ $L=200 \mathrm{~m}$ ，である. また，地山応力にかかわ る物性値は岩盤分類上中級程度の花崗岩を想定し, 岩盤 の弾性係数 $E_{r}=14.7 \mathrm{GN} / \mathrm{m}^{2}$, ポアソン比 $M_{r}=0.3$, 単 位体積重量 $\gamma_{r}=25.5 \mathrm{kN} / \mathrm{m}^{3}$, 上部沖積層の単位体積重

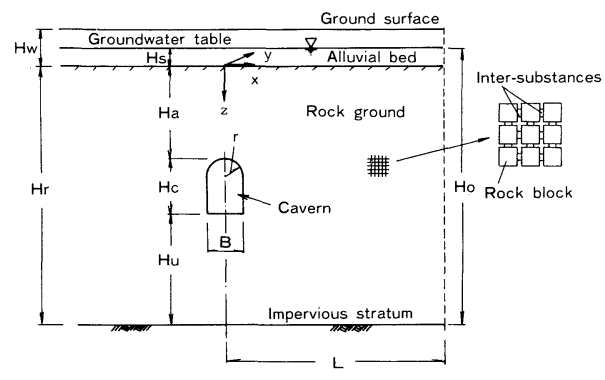

Fig. 8 Cavern model in rock mass model.

Table 1 Computational conditions.

\begin{tabular}{|c|c|c|c|c|c|c|}
\hline Cases & $\begin{array}{l}\text { block size } \\
\mathrm{S}_{0}^{\prime} \\
(\mathrm{m})\end{array}$ & $\begin{array}{c}\mathrm{aE}_{\mathrm{c}} \\
\left(\mathrm{MN} / \mathrm{m}^{2}\right)\end{array}$ & $\begin{array}{l}\text { intersitial } \\
\text { width } \\
d_{0} \\
\left(\times 10^{-5} \mathrm{~m}\right)\end{array}$ & $\begin{array}{c}\text { porosity } \\
n_{0} \\
(\%)\end{array}$ & 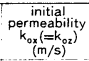 & pa \\
\hline$n-1$ & 0.1 & & 1.15 & $6.9 \times 10^{-2}$ & \multirow{2}{*}{$2.0 \times 10^{-7}$} & \multirow{4}{*}{ 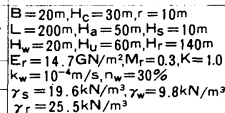 } \\
\hline n- 2 & 1.0 & & 8 & & & \\
\hline-3 & 1.0 & & & -3 & $2.0 \times 10^{-}$ & \\
\hline un- 4 & 1.0 & & 0.425 & $2.55 \times 10^{-3}$ & $1.0 \times 10^{-9}$ & \\
\hline
\end{tabular}

量 $\gamma_{s}=19.6 \mathrm{kN} / \mathrm{m}^{3}$, 水の単位体積重量 $\gamma_{\omega}=9.8 \mathrm{kN} / \mathrm{m}^{3}$ とし, 岩盤初期地山の側圧係数 $K=1.0$ とする. 一方, 岩盤の透水性にかかわる值として, 基準状態の透水係数 $k_{0}$ は $1.0 \times 10^{-9} \sim 2.0 \times 10^{-7} \mathrm{~m} / \mathrm{s}$, ブロックの辺長 $s_{0}^{\prime}=$ 0.1 および $1.0 \mathrm{~m}$, 介在柱にかかわる定数 $a E_{c}=2.8$ $5.9 \mathrm{MN} / \mathrm{m}^{2}$, 基本割れ目幅の $1 / 2, d_{0}=0.425 \sim 2.48 \times$ $10^{-5} \mathrm{~m}$, 空隙率 $n_{0}=2.55 \times 10^{-3} \sim 6.90 \times 10^{-2} \%$ ，とする. また, 上部沖積層のそれは, 透水係数 $k_{w}=1.0 \times 10^{-4}$ $\mathrm{m} / \mathrm{s}$, 空隙率 $n_{w}=30 \%$ で一定とする. 解析は FEM 法 によって, 表中の Run - 1 4 に分けて行うが, 要素形 状は四角形とし要素は 307 , 節点数は 345 とした。

\section{（2）解析方法と手順}

解析は, 本論で新たに導いた基礎式（9)，(10)，(23） を用いて応力解析と coupling させて計算することにな るが地下水解析は Galerkin 有限要素法によって行い, 応力解析はアイソパラメトリック要素を用いた線形弾性 解析とし, 有限要素法によっている. 本モデルにおける 今回の解析の場合, 非定常性は空洞掘削の初期に限られ るので, 実用上の観点から，ここでは定常流場に限定し て解析を行うこととする.

いま，ここで用いた岩盤の応力解析の考え方と方法を 説明する. 解析は, 線形弾性理論に基づいて行っており, 岩盤は等方であり，かつ上述したように対象とする場は 平面ひずみ状態 $\left(\varepsilon_{y}=0\right)$ にあるとすると, Hooke の法 則および微小変形弾性理論から応力ーひずみ・変位の関 係式は，任意の要素に対し，

$$
\begin{aligned}
& \left\{P_{t}\right\}=\left\{\begin{array}{l}
P_{t 3} \\
P_{t 1}
\end{array}\right\}=\frac{\bar{E}_{r}}{\left(1+M_{r}\right)\left(1-2 M_{r}\right)}\left[\begin{array}{cc}
1-M_{r} & M_{r} \\
M_{r} & 1-M_{r}
\end{array}\right]\left\{\begin{array}{l}
\varepsilon_{3} \\
\varepsilon_{1}
\end{array}\right\} \\
& =[C]\{\varepsilon\} \\
& P_{t 2}=M_{r}\left(P_{t 1}+P_{t 3}\right)
\end{aligned}
$$




$$
\{\varepsilon\}=\left\{\begin{array}{l}
\varepsilon_{3} \\
\varepsilon_{1}
\end{array}\right\}=\left\{\begin{array}{l}
\partial u / \partial x \\
\partial w / \partial z
\end{array}\right\}=[B]\{\delta\}
$$

と表わせる ${ }^{20)}$. ただし，せん断ひずみ成分は直応力成分 のみに着目するため,ここではその基礎理論を省略する. ここに, $\bar{E}_{r}$ : 岩盤の等価弾性係数, $\varepsilon$ : 各方向成分の縦 ひずみ, $[C]$ : 弾性マトリックス, $u, w: x, z$ 軸方向 の変位ベクトル成分, $[B]:$ ひずみマトリックス, $\delta$ : 要素の節点変位である. また, 要素が結合された全構成 系における節点力と節点変位の関係, つまり剛性方程式 はよく知られているように

$$
[D]\{\delta\}=[F] \text {. }
$$

となる.ここに, $[D]$ : 各要素の剛性マトリックスより 合成される全構造系の剛性マトリックス, $[F]$ : 各節点 に働く外力である.したがって，

$$
\{\delta\}=[D]^{-1}[F] \cdots
$$

を算出し，それを式 (24)，（26）に代入することにより 応力成分を算定することができる ${ }^{201}$.

ここで，実際の計算にあたって，等価弾性係数 $\bar{E}_{r}$ はマ トリックス $[D]$ が, $\bar{E}_{r}\left[D^{\prime}\right]$ と表わせるから, 式 (24) において消去されることになって,解析上は不要となる. 本解析における節点外力は空洞壁面における掘削相当外

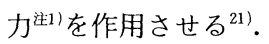

結局, 式 (24) （28）で得られる応力值を透水係数式 （9）に代入して, 式（23）の定常流基礎式を解くこと になる. Fig. 9 は，その解析手順をフロー図で示したも のである. 解析手順は, 初期地山における初期透水係数 分布を設定し，必要な境界条件下においてピエゾ水頭分 布を求めて, 次にその値と空洞掘削後の応力分布より新 たな透水係数を計算する. 解析はピエゾ水頭と透水係数 が同時に収束するまで繰り返し計算によって行われる. ピエゾ水頭および透水係数分布が決まると, 空洞涌水量 は求めることができる.

\section{(3) 解析結果とその考察}

Table 1 に示した解析条件に基づいて Run-1 4の 4 ケースにおける解析を行い, 空洞周辺の透水性の変化に 注目して検討を加える.

初めに, Fig. 10 は空洞掘削後の $x, z$ 方向応力の分 布を示したものである. 図中，実線の長さは応力値の大 きさを表わすが，この場合はほとんど引張応力は生じな い. 従来, 上く知られているように応力変化は空洞近傍に 限られ, 特に空洞側面近傍の水平方向応力 $P_{t x}$, および底 面下の鉛直方向応力 $P_{t z}$ は非常に小さくなっている.

次に, こういった応力場において, 空洞掘削後の定常 地山透水係数がどのように変化するかに注目することに

注 1）掘削により掘削面は表面応力が 0 の解放表面となる が, この応力 0 の自由表面状態を作るため掘削面の構成節点 に載荷する節点外力を掘削相当外力と称する.

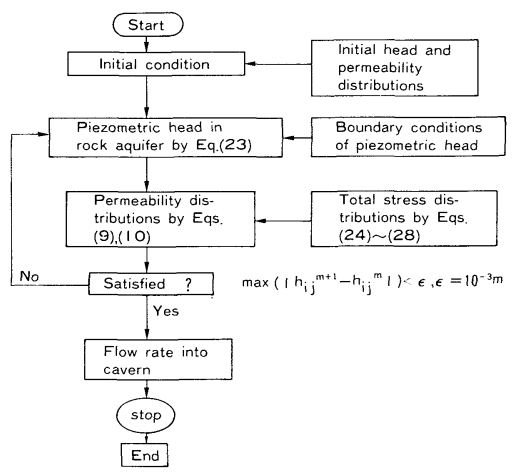

Fig. 9 Computational procedure of proposed analysis.

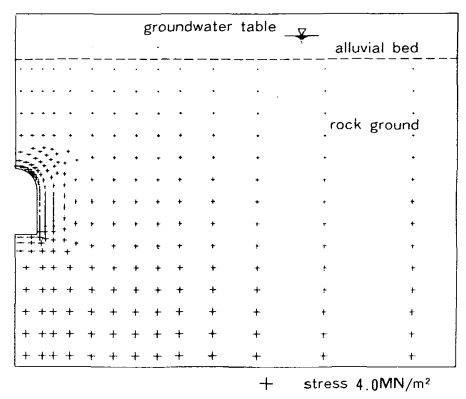

Fig. 10 Distribution of stress $P_{t x}, P_{t z}$ around cavern.

する. Fig. 11 は Run-1〜4 (Table 1参照) における透 水係数分布を基準状態の透水係数 $k_{0 x}, k_{0 z}$ との比で示 したものである．まず，Run-1 とRun-2 の結果は計算 条件上ほとんど同じであるので区別して示しにくい。つ まり，幾何学的にみて透水係数はブロック寸法 $s_{0}^{\prime}$ によっ てほとんど影響されないことを示している．透水係数分 布 $k_{x} / k_{0 x}, k_{z} / k_{0 z}$ は空洞より遠方では地下水流れの影 響を受けないため初期地山における分布と同じであり， 深度のみに依存して小さくなる。こういった遠方では側 圧係数 $K$ は 1.0 であるから当然 $k_{x}$ と $k_{z}$ は等しい. 空 洞近傍では, 応力状態の変化に伴って $k_{x}$ は底部および 側面で大きくなっている，いわゆるゆるみ領域が現われ る. 一方 $k_{z}$ は上半円面, 底面で小さくなり, また側面 では $k_{x}, k_{z}$ ともに底面角部近傍で著しく小さくなって いることも認められる.ここでは圧縮力が支配的となる. 次に，(b) および（c) は，おのおの Run-3, Run-4の $k_{x} / k_{0 x}, k_{z} / k_{0 z}$ 分布を示したものであり, 全体的な傾 向はRun-1 のそれと類似のものとなっている. しかし ながら, Run-3, 4 の $k_{x} / k_{0 x}, k_{z} / k_{0 z}$ の変化量は, Run-1のそれに比べて小さくなっている.これは，上 述した初期地山における透水係数特性においてみられた ものと同様であって, $a E_{c}$ が大きいため応力変化が小 さいことに起因するものといえる.

ここで，このような透水係数分布をもつ空洞掘削地山 における圧力水頭分布および流速べクトルがざうなる 


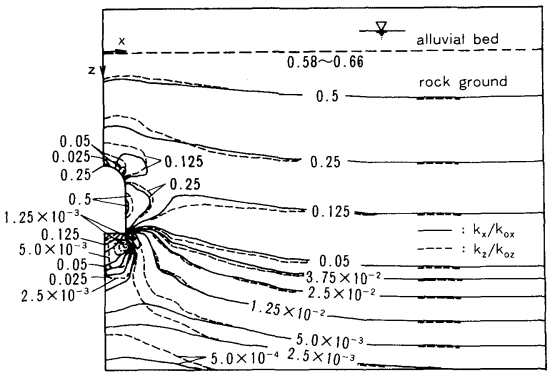

(a) Computed results of Run-1 and Run-2

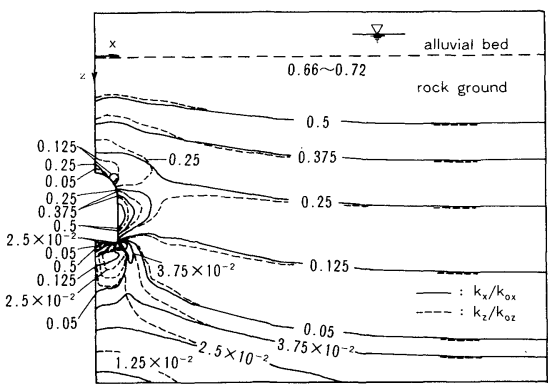

(b) Computed results of Run-3

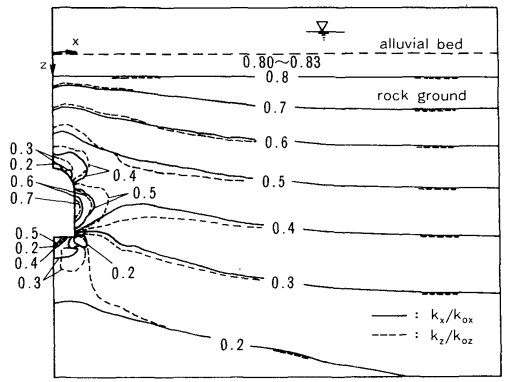

(c ) Computed results of Run-4

Fig. 11 Distributions of non-dimensional permeability $k_{x} / k_{0 x}, k_{z} / k_{0 z}$ in rock mass models.

か，Run-1 および Run-4 のそれらと比較のため地山を 不変形等方均質場 (つまり, 透水係数の空間分布がなく, 全体に一様で水圧変化との相互作用もない場）とした場 合のそれを示した Fig.12についてみてみる. 図中, $\bar{k}$ は空洞を等価断面円形とした場合の Aravin の式 ${ }^{6}$ (つま り，水底帯水層に円形トンネルを設けた場合の湧水量を 写像解析した定常理論解) を用いて涌水量から不変形等 方均質地山之して逆算した平均透水係数（Table 2 の計 算条件は同じ）であって，無次元流速べクトルはそれと の比で示してある.これらより空洞近傍の圧力水頭に着 目すると, 圧力水頭は $a E_{c}$ の小さい Run-1 の場合に周 辺透水係数の減少に起因して最も大きくなっており，均 質場の場合のそれは小さい。また，流速ベクトルは Run-1 の場合, 空洞側面で大きく上半円面では水平方 向にややゆがみ，底面でかなり小さくなっている，均質 地山の場合の分布（壁面での流速ベクトルはほぼ一様で

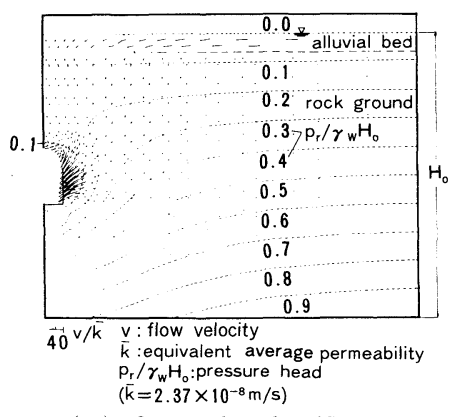

(a) Computed results of Run-1

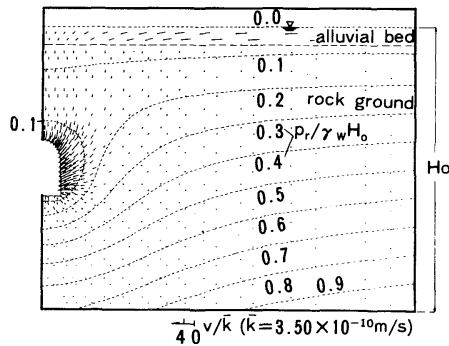

(b) Computed results of Run-4

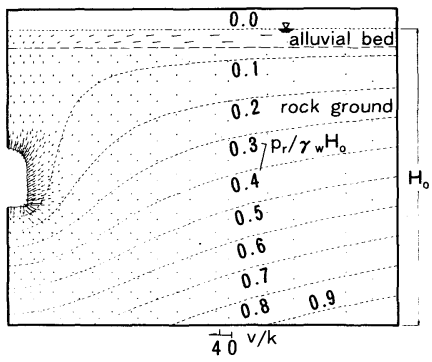

(c) Undeformable rock mass

Fig. 12 Flow patterns and distributions of pressure head.

ある）と比べてかなり異なっていることが認められる.

Table 2 はこのことをわかりやすくするため, 空洞へ の涌水流量成分を底面，両側面，および上半円面の 3 つ の成分に分け単位面積当たりの無次元湧水量を示したも のである. 表中, $q_{t}$ : 総湧水量 $\left(q_{t}=q_{a}+q_{b}+q_{c}\right), A_{t}$ : 単位奥行長さ当たりの空洞壁面の総面積 $\left(A_{t}=A_{a}+A_{b}+A_{c}\right), q_{a} ， q_{b}, q_{c}$ : 区分されたおのおの の壁面からの湧水量, $A_{a}, A_{b}, A_{c}$ : 区分されたおのお のの壁面の面積, さらに添字 $a, b, c$ : おのおの, $\mathrm{a}$ 底面, $\mathrm{b}$ 側面, c 上面, での值を示している.これらより, Run-1では側面涌水 $q_{b} / \bar{k} A_{b}$ が大きく, 底面湧水 $q_{a} / \bar{k} A_{a}$ はそれに比べかなり小さくなっているが, Run-3, 4 となると $q_{b} / \bar{k} A_{b}$ はやや減少し, 逆に $q_{a} / \bar{k} A_{a}$ はかなり増加してその差が小さくなってくるこ とが認められる。つまりこのことは，こういった地山モ デルにおける空洞周辺の透水性変化は, 特に空洞底面か らの湧水量に大きく影響を与えることを明らかにしてい る. また，平均透水係数比 $\bar{k} / k_{0 x}$ と Fig. 11 で示した透 
Table 2 Calculated results of flow discharge rate into cavern.

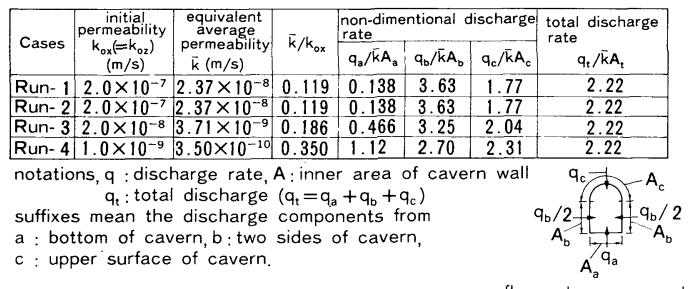

flow rate components

水係数分布を比較してみると, $\bar{k} / k_{0 x}$ の值はいずれの場 合も空洞より遠方において底面レベルのそれに近いもの となっている.

\section{（4）ゆるみ領域における現場実測結果との比較}

掘削工事の安全性確保のうえで重要な空洞周辺ゆるみ 領域の透水性に焦点を当て, その透水係数の変化につい て検討を加えることとする.残念ながら, 実験的には均質 地山の応力場のみでも再現することがきわめて難しいこ とに加え，本モデルのように弾性岩塊ブロックでそれを 行うことは実際上不可能に近いと思われる。ここでは多 少不確定な要因や精度に問題を含むと思われるが空洞掘 削フィールドにおける実測データを用いて検討する.

Fig. 13 は, 空洞周辺のゆるみ領域と透水係数の変化 を弾性解析といくつかの現場計測をもとにして示したも のである.図の中心線より左側は上半円形空洞における 従来の均質地山線形弾性応力解析結果より側圧係数 $K$ $=1.0$ として得られた理論的ゆるみ領域(破壊接近度 $R^{\text {注 2) }}$ が 1.5 以下の範囲 ${ }^{22)}$ ) を表わしている.その側方幅は $D / B=0.25 \sim 0.3$ 程度となっている. 右側は上述の本論 計算結果のうち Fig. 11 (a)，Run-1 の場合に相当する 透水係数の変化・分布を基準状態の透水係数との比で示 してある．また，側壁垂線上の透水係数分布は実測デー 夕であって空洞の遠方での解析透水係数を用いて併せて 提示した。これより, 応力解析から求まったゆるみ領域 の分布形状は，側壁部で大きく上半円形面部では逆に小 さくなっている.これと本論の解析で得られた Fig. 11, Run-1 の $k_{x} / k_{0 x}$ および $k_{z} / k_{0 z}$ が 0.25 の分布形状を比 較してみると, 両者はよく似たパターン形状をなしてい る.このことは, 応力開放によって空洞壁面はゆるみ, 亀裂は変位方向に開口して透水性が増加することは現場 でもあり得ることを示す.

次に，各壁の垂線上の透水係数に目を転じると，いず

注 2）破壊包絡線 $\left(\left(\tau / \tau_{r}\right)^{a}=1-\sigma / \sigma_{t}, \tau\right.$ : 見掛けのせん断応 力, $\tau_{r}$ : 世 $ん$ 断強度, $a$ : 破壊包絡線指数, $\sigma$ : 見掛けの直応力, $\sigma_{t}$ : 引張強度）とモールの応力円との最短距離 $d_{\min }$ をパラ メーターにして表現し, 引張強度 $\sigma_{t}$ と応力円の中心点との距 離 $\sigma_{t}-\left(\sigma_{1}+\sigma_{2}\right) / 2$ を $d_{\text {min }}$ を割った值を破壊接近度 $R\left(=d_{\min } /\left(\sigma_{t}-\left(\sigma_{1}+\sigma_{2}\right) / 2\right)\right.$ とする従来の定義に従う.ここで, $\sigma_{1}, \sigma_{2}:$ 主応力である.

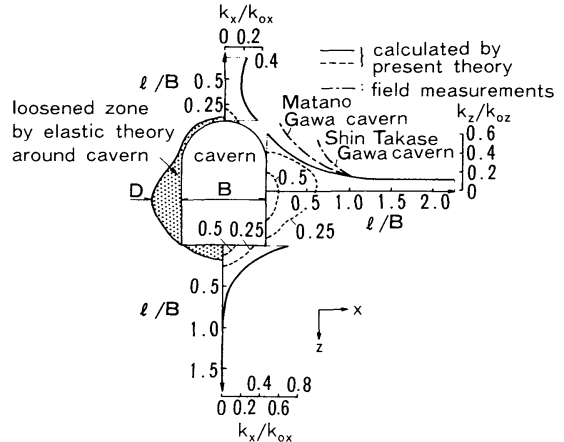

Fig. 13 Permeability distributions by field measurements and loozened zone around cavern.

れの場合も空洞壁面が最大となり，離れるにつれて減少 している.その影響範囲を空洞壁面からの距離 $l$ と空洞 幅 $B$ との比で示せば, 天端部は $l / B=0.2$, 側壁部 1.0 , 底版部 0.5 程度となっている。しかし，その変化は底版 部で最も著しく，ついで側壁部，天端部の順になってい る.他方，側壁部における実測データと計算結果を比較 してみると，その影響範囲および傾向はよく一致してい るようにみれるものの, 透水係数の増加の程度は実测 データの方がかなり大きくなっており，特に壁面より 2 ～ $4 \mathrm{~m}$ の範囲（ $B=20 \mathrm{~m}$ とすると $l / B=0.1 \sim 0.2 ）$ では 遠方のそれに比べ数十一数百倍となっている ${ }^{23) \sim 26)}$ ，こ の原因としては，掘削発破やブレーカーによる直接的損 傷により，新たな亀裂の発生に加え亀裂の開口と変位に よるものと考えられるが23) 26)，このほかに地質はもと より，掘削手順および奄裂の分布・性状といった固有の 諸要因にも関係してくるものと考えられる．しかしなが ら，現場計測による透水性の面からみたゆるみ領域の範 囲と分布構造は本論で得られた解析結果からかなり明確 にされたものと考える。

\section{6. 結 論}

岩盤地下空洞に代表される近年の岩盤利用の多様化に 伴って, 岩盤地下水と岩盤力学現象の解明が強く望まれ ている. 本研究は, 介在柱をもつ岩塊モデルを導入して, 岩盤地山における地山応力と地下水の連成解析を可能に し, 従来不明確のままであった岩盤地山の透水特性のい くつかを解明することができた．本研究で得られた成果 は以下のように要約される. (1) 岩塊モデルを用いるこ とにより，亀裂系岩盤地山における応力一地下水連成解 析が可能となる. (2) 岩盤地山の透水係数は, 深度の増 加につれて小さくなり，かつその低下率も対応して大き くなることが現地実測結果によるのみならず理論的にも 実証された。また，それは地山の初期地圧の影響を受け， 側圧係数 $K$ が $K>1$ の場合は, 水平方向の透水係数に 
比べ鉛直方向の透水係数の方が小さくなるが， $K<1$ の 場合は逆にそ机は大きくなる. (3) 介在柱にかかわる定 数 $a E_{c}$ は, 基準状態の透水係数を知ることによってあ る程度推定できる. (4) 上半円形空洞掘削により地山透 水係数は空洞周辺近傍ゆるみ帯で全体的にはやや大きく なる。しかし，空洞壁面のごく近傍に限定すると，側面 の水平・鉛直方向および底面の水平方向のそれは大きく なるが，上半円面および底面鉛直方向では小さくなる．

(5) 岩盤地山の応力状態の変化に伴う透水係数の変化 は，介在柱にかかわる定数 $a E_{c}$ に大きく影響され， $a E_{c}$ が小さいと特に顕著となる，空洞周辺のゆるみ領 域における透水係数は $a E_{c}$ が小さいと大きくなり，同 時に圧力水頭も大きくなって側方よりの流入涌水が支配 的となってくる. (6) 空洞掘削による応力依存ゆるみ帯 之透水係数の増大域，つまり透水性の面からみたゆるみ 帯は，定性的によく似ており形状分布も類似している.

(7) ゆるみ帯による透水性の変化は空洞幅の $0.2 \sim 1.0$ 倍の範囲で生じるが, 側壁部におけるそれが最も大きい. また，その変化率は底版部で著しく大きくなる，8)ゆ るみ帯の透水係数は空洞壁面に近づくにつれて大きくな るが，実際の地山掘削では発破，削岩等による工事損傷 もあって本論のモデルで計算される值よりかなり大きな ものであった．最後に本研究にあたって現場資料を提供 していただいた鹿島建設（株）技術研究所の青木謙治氏 にお礼申し上げます。

\section{参 考 文 献}

1）林 正夫・駒田広也：原子力発電所構造物の設計と施工 一地下立地, 土木学会誌, pp. 36〜42，1978.4.

2）桜井俊男：石油地下備蓄菊間プラントについて，土質工 学会「土と基礎」29-1 (276), No.1210, pp. 15 22, 1981.

3）田坂広志・清瀬量平：米国の諸研究機関における放射性 廃棄物処分の安全評価に関する研究の現状, 日本原子力 学会誌, Vol. 22, No. 5, pp. 308 320, 1980.

4）駒田広也ほか：岩盤内圧縮空気貯蔵空洞からの漏気に関 する検討, 第 17 回岩盤力学に関するシンポジウム講演論 文集，pp.171 175，1985.2.

5）駒田広也ほか：水封式燃料地下貯蔵用空洞周辺岩盤の浸 透流に関する検討，土木学会論文報告集，第 300 号， pp. $69 \sim 80,1980.8$.

6）伊藤 洋ほか：岩盤地下空洞の地下水に関する実験的研 究, 土木学会論文報告集, 第 342 号, pp. 97 106, 1984. 2 .

7）伊藤 洋ほか：地下空洞周辺の地下水流れおよび伝熱の 三次元特性に関する研究，第 17 回岩盤力学に関するシン ポジウム講演論文集, pp. 181〜185，1985.2.
8) Snow, D. T. : Fracture deformation and changes of permeability and storage upon changes of fluid pressure, Quarterly of Colorado School of Mines, Vol.63, No.1, pp. 201 244, Janu. 1968.

9) Sato, K. and lizawa, M. : Ground water analysis of underground cavern by means of rock block model, Soils and Foundations, Vol.22, No.4, pp. 30 44, Dec. 1982.

10）佐藤邦明：岩盤浸透流の抵抗則について, 土質工学会「土 と基礎」, 30-12 (299), No.1341, pp.27〜32, 1982.

11) Timoshenko, S. and Young, D. H. : Elements of strength of materials, D. Van Nortrand, Company, Inc. Princeton, pp. 55 59, 1962.

12) Carlson, A. and Olsson, T. : Variation of hydraulic conductivity in some Swedish rock types, Rock Store, Proc. First Int. Sym. Stockholm Sweeden No. 2, 1977.

13) Gale, J. E . et al. : Hydrogeologic characteristics of a fractured granite, AWRC Conf. Ground water in Fractured Rock, Canberra, pp. 95 108, 1982.

14）渡辺邦夫・小島圭二：断層・割れ目系岩盤中の地下水流 れと関与する地質量の計測と評価，昭和 55 年度日本応用 地質学会シンポジウム論文集, pp. 2 17, 1980.

15）土木学会編：岩盤力学, pp. 169 177, pp. 505 510, 1979.

16）林 正夫ほか：原子力発電所の地下立地における発電所 空洞の安定性, 電力中央研究所報告, No. 379008, pp. 68 $\sim 83,1979.11$.

17）日比野敏ほか：水封式燃料地下貯蔵の技術開発に関する 研究, 電力中央研究所報告, No. 379001, pp. 1 23, 1979.7.

18）野口俊郎ほか：大規模地下発電所の設計と空洞周辺岩盤 挙動計測, 土質工学会「土と基礎」, 29-1 (276), No. 1212, pp. 29 36, 1981.

19）鈴木 光: 岩盤の計測と解析, 土木工学社, pp. 202 228, 1982.

20）川本眺万・林 正夫：地盤工学における有限要素解析, 培風館, 1978.

21）本島 勲ほか：大規模な地下構造物掘削時の安定解析プ ログラムの開発とその適用例, 電力中央研究所報告, No. 376011, pp. $11 \sim 12$, pp. 32 35, 1977.6.

22) 前出 21), pp. 23 27.

23）本島 勲・金析裕司：花崗岩地域における地下空洞掘削 に伴う透水度の変化に関する考察, 電力中央研究所報告, No. 382053, pp. 1〜25, 1983. 3.

24）本島 勲：地下発電所の空洞掘削に伴う周辺岩盤におけ る透水度の変化に関する考察, 電力中央研究所報告, No. 379009, 1979.

25）本島 勲：地下発電所空洞周辺における地下水圧低下工 法に関する考察，電力土木, No. 177, pp. 65 75, 1982.

26）井上大栄：空洞掘削に伴う節理の多い岩盤のゆるみ性状 に関する検討, 電力中央研究所報告, No. 381017, pp. 1 $\sim 30,1981.11$.

(1985.5.7 ·受付) 